\title{
The Design and Implementation of Network Courses for Free Combat
}

\author{
Xu Hailong \\ Wushu Department \\ Hebei Sport University \\ Shijiazhuang, China \\ xuhailonghebei@yahoo.com.cn
}

\author{
$\mathrm{Ma} \mathrm{Na}$ \\ Wushu Department \\ Hebei Sport University \\ Shijiazhuang, China \\ xuhailonghebei@yahoo.com.cn
}

\author{
Ma Minqing \\ Wushu Department \\ Hebei Sport University \\ Shijiazhuang, China \\ xuhailonghebei@yahoo.com.cn
}

\begin{abstract}
Currently, network technology is applied to teaching generally and becoming the necessary demand of all types and levels of school. The paper provides the design of the overall structure of free combat network course, system implementation technology and system features, which will offer an effective method for construction and structure of network course to push the reform of methods and means of colleges forward, according to the actual need of physical education.
\end{abstract}

Key words- Free Combat; Network Course; Design; Implementation

\section{INTRODUCTION}

The appearance of modern network-based distance teaching promotes fundamental changes of all kinds of information technology. Showing teaching content, implement teaching activities and diffuse advanced theories, methods and experience speedily through network have been the important part of teaching reform of higher education. Ministry of Education has set the construction of distance network courses as an important part of construction of national higher education courses. Free combat, a required course for ethnic traditional sports major, is a practice technical course involving different types of sport techniques of run, walk, jump and throw. In conventional teaching, teachers have to show actions by their own to visualize each technique of free combat and show the complete technique in a dynamic way. However, to the self-learning students and correspondence students who lack of visual basis of correct techniques, the conventional way will restricted their learning seriously. With the rapid development of network technology, the networked free combat course has technical support and conditions guarantee. Research and develop "web-based free combat network course teaching system" (http://www.nwnu.edu.cn/tyxy/track and field) are requirements of the times for higher education and actual demands of teaching reform for PE technique-related courses under the rapid development of teaching modernization and networking.

\section{Global Structure DESIGN OF Free Combat NETWORK COURSE TEACHING SYSTEM}

\section{A. General Goal Design of System}

Distance network teaching system consists of web browser, web server, teaching database server, etc and the core of system is the establishment of teaching database. The paper is based on the teaching book Free Combat, which is published by Higher Education Press, and in accordance with the guidance of constructivism theory to construct a self-learning network course of free combat with forms of expression as many excellent athletes' techniques short films, DV-shot teaching videos, action technique animations, audios, videos, texts, etc for students. The network course shall be used for modern distance teaching, assisting teachers' teaching and students' study to satisfy the self-learning need of college students and correspondence students.

Web browser: Web browser is located on client-side with main functions of sending studying requests to web teaching server and transferring required web pages to clients and display them on the web browser.

Web server: Web server is mainly used to analysis studying requests of students (user) and transfer feedback that data application server makes back to students (user). If web browser requests a simple HTML document, web server will send back the relevant document; if web browser requests special documents, web server will transmit the request to application server. The application server will process the data and return the result to web server, then web server sends the result in HTML format to web browser.

Database server: Database server, which consists of course content library, excellent athletes' techniques images and videos library, teaching resources videos library, object library, strategy library, parameter library, etc, is a collection of all network teaching resources. The server will accept the request that application server operates database to achieve functions of inquiry and update of data, then the result will be submitted to application server.

\section{B. Design of System Technical Route}

All kinds of course resources in the database server are the core of development of system design and implementation. The make of all kinds of course resources must in accordance with thoughts of overall development.

\section{System Teaching Design}

\section{1) Teaching Program}

Teaching program of free combat has stipulated content, system and scope of the subject. It is an outline document for teaching and has stipulated teaching goals, teaching tasks and content of free combat course. It is not only the fundamental basis of free combat teaching, but also one of measures for examining teaching quality. The design of 
teaching program mainly contains teaching goals and tasks, arrangement of class hours, teaching materials and teaching reference books, arrangement of chapters of course, etc.

\section{2) The Design of Content of Course}

The content of free combat network course mainly includes history of free combat development, teaching theories and methods of free combat, technical theories of free combat, rules and judging regulations of free combat, technical teaching of free combat (fists, legs, throw) according to requirements of teaching program. The teaching of each part will adopt module teaching. The module is on the basis of teaching unit, which means the content of course will display on the page with good navigation structure and regards a technical teaching unit of sport items as a unit, as per independence principle of module partition. The whole functional modules of system contain teaching program, teaching progress, teaching of all kinds of free combat techniques, videos of excellent athletes' techniques and teaching practice, teaching forum, teaching comments, relevant websites' links, website's feedback, etc.

\section{3) Forms of Expression of Content of Course}

The network page will adopt framed structure to establish three zones: top frame is navigation zone, left frame is catalogue zone of courses and right frame is course teaching zone. Using excellent athletes' techniques videos shot by DV camera and Flash as main forms of expression in teaching. Animations and excellent athletes' techniques videos shall be able to be made into digital films, which can be played, paused and replayed in slow mode. Meanwhile, static images, which are shot from different angle, can be used as form of assistance. The teaching text adopts concise high-summarized text description and creates hierarchical effect by the using of font, font size, color, foreground color and background color. Free combat course is a subject that emphasizes on technical teaching, so the network course is adopted a way of playing videos to teach techniques for establishing correct impression for learners. The network course adopts stream media technology to make original videos into stream media format, edit them properly as per teaching requirements and dub explainable voice into them.

\section{System Teaching Functions}

\section{1) Release Function of Content of Course}

This module offers online content of relevant courses released by teachers and provides students with learning content and search function. Learning content includes all knowledge points of course, key points and difficult points summarized by teachers. Search function provides students with relevant information inquiry, including online study in HTML format, e-teaching plans in PPT format, teaching documents in DOC format, teaching videos in RM format, etc, in accordance with specific study requirements in the whole network courses. This part is the key part of network course teaching system and online learning content is adopted net structure, which can organize all knowledge points of free combat course orderly for students' selflearning and provide numerous Flash animations and excellent athletes' techniques videos in RM format for hard understanding concepts and content to promote students' learning efficiency.

\section{2) Homework Function}

This module includes two sub-modules for teachers and students respectively. Students' sub-module allows them to upload their homework in RAR format, check assessment of their homework, etc. Teachers' sub-module allows them to assess students' homework and give marks for inquiry. After finish each unit's learning, students can use online homework module examine their study achievements. The content of homework is mainly emphasis on the student's apprehension to knowledge points of the unit.

\section{3) $Q \&$ A Function}

This module includes two sub-modules of real-time Q \& A and non-real-time Q \& A. The implementation of realtime $\mathrm{Q} \& \mathrm{~A}$ is by chat room technology, which allows teachers and students to log in simultaneously and communicate with each other in real time online. The implementation of non-real-time Q \& A is by discussion group technology, which assures teachers answer students' questions expediently. If a learner has problems during studying, he may discuss with other students or teachers through course forum to acquire answers.

\section{4) Online Exam Function}

Online exam module mainly provides exams for learners so that they can have an overall apprehension of what they have learned in accordance with the exam result. Students could choose content and question type of exam by themselves. When the exam is finished, they could click the "Automatic Grading" button to acquire the result. Students could log in the online exam after sign up and the module can form an exam paper at random by computer and assess it automatically and give all correct answers. Students could do exercises in the network course to test their level, consolidate what they have learned and find out their weakness.

5) Course Discussion and Communication Function

Online forum module provides exchange platform for learners. There are free discussion zone and topic discussion zone in this module. The former is mainly for discussion of knowledge or relevant topic for learners, topic discussion zone is mainly for teachers to discuss typical questions proposed by learners or forward-looking questions within the subject.

\section{6) System Management Function}

This function, which is achieved by logging in the system, can provide ID certification and access permission certification for learners, teachers and administrators. This module will record log-in users and file registered users' information. For the user who have logged in, after he inputs his account name and password, the page will turn into an appropriate page after the system identifies his ID. Teacher users need to be confirmed by administrators.

\section{THE IMPLEMENTATION OF SYSTEM MAIN FUnCTIONS}

The prerequisites of implementation of system functions are the make of all kinds of network course resources, the 
general make of network courseware, system interface design and port technology.

\section{A. The General Make of Network Courseware}

Teaching texts made by the software Word 2003 and original teaching media materials recorded by DV camera, digital camera and video recorder and scanned by scanner will be processed into free combat courseware by software of Photoshop 6.0, Flash 7.0, 3DMax, etc. Finally, web development software of Authorware 7.0 and Frontpage 2000 will be used to integrate free combat media materials into system platform on the basis of script design of courseware content, teaching methods and steps, refined training methods, screen layout, information display mode, interaction mode, learning process control, etc. After that, they will be transferred to campus network server, which will be free combat network courseware finally.

\section{B. The Make of All Kinds of Network Course Resource}

\section{1) The Make of Text Materials}

Teaching texts, which will be saved into computers, are made by software Word 2003 with sentences that are concise and easy to understand to explain every sport technique in teaching materials after knowledge points of teaching program are selected.

\section{2) The Make of Sport Technique Videos}

Free combat technique videos, contain techniques used in the Olympic Games or World Championship by athletes, are shot by DV camera. They will be made into digital films in $\mathrm{RM}$ format to be played by the software Realplay after they are transferred to computers with data wire. The courseware system will be applied Active Control to playing videos in real time.

\section{3) The Make of Animation Course Resources}

Free combat techniques will be made into animation course resources by software of Flash MX 2004, Authorware 7.0 and 3Dmax with hot keys to make convenient for students' repeated watch and learning.

\section{4) The Make of Images}

Search free combat technique images by internet search engine, take free combat technique images by digital camera and scan colored free combat technique images in teaching materials and magazines by scanner. All those images will be saved in the computers and processed by the software Photoshop 7.0 for courseware materials used.

\section{Interface Design and Port Technology of Free Combat Network Course System}

Interface design of free combat network course system should strive for conciseness with windows of listing detailed branches of content of teaching, which can be clicked to choose learning content. The main interface of system is the first grade interface, which divides free combat knowledge into five parts: history of free combat development, free combat techniques, technical theories of free combat, rules and judging regulations of free combat and technical teaching of free combat. There are buttons within the window. If you click any one of them, the page will turn into the next grade interface, which displays classification of specific knowledge points that each button contains. Click words in the hot zone, the page will turn into the third grade interface, which displays specific content of each knowledge point with teaching examples in text, digital films, images and animations forms.

\section{SYSTEM FEATURES}

\section{A. Openness}

Learners (include college students, correspondence students and adults) will have the authority to enjoy the fullopen free combat network course resource, flexible and diverse learning strategies and supports after they sign up (sign up is no charge). Meanwhile, the system breaks the region and space time constraints and brings teaching and learning out of class. It provides the opportunity for students to communicate with the world and improves college free combat course by taking instructive advice. Students are free to choose time to visit teaching system of the website by computer to do self-learning as per their own progress in different places. They also could collect materials through Internet and seek arguments for exploratory research to enlarge their range of knowledge and promote resource efficiency.

\section{B. Characteristic}

The teaching mode turns from conventional teachersleading to students-leading with teachers' guidance, from fixed space time and class-leading to self-learning by individual-leading without space time constraints on this web-based network system. The system can adapt to learners' characteristics in aspects of organization and appearance of content of course, system navigation and strategies for students' self-learning. Except that, students could imitate techniques and correct wrong actions by videos.

\section{Diversity}

The free combat network course is making full use of digital films, videos, etc information resources with substantial content, massive information and creative thoughts. It integrates various forms of teaching materials words, images, animations, audios, etc multimedia into one with vivid multimedia effects, which present free combat technical concepts, basic principle and all kinds of questions in various ways.

\section{Wide Applicability}

It is not only applicable for college students' distance learning, but also for teachers' use by providing the best materials for teaching plans, which is helpful to achieve resources sharing, avoid repeated construction, promote efficiency and save expenditure.

\section{E. Interaction}

The development of free combat network course allows two-way education become possible. The information of teachers and students is processed in two-way mode, which can make the understanding of information conveniently, 
timely and easily, increase the time-validity of information utilization and promote mutual progress of teachers and students. The real-time discussions between teachers and students can let teachers know students' learning conditions from their feedback and make adjustments of the content of website timely, and students can get instructive advice from teachers and adjust their learning progress.

\section{REFERENCES}

[1] Technical Regulation of Modern Distance Education Resource Construction [DB/OL].http://www.edu.cn/html/keyanfz/.2002- 9-15.

[2] He Kekang. Education Technology [M].Beijing: Beijing Normal University Press, 2002.2 10.

[3] Shen Ning. On Construction of Network Teaching Resources Library under the Constructivism Guidance [J].Educational Communications and Technology, 2003, (3): 6 9.

[4] [Zhu Rencheng, Zhu Li, Chen Lisheng. Multimedia CAI Courseware Making Tutorial [M].Xi'an: Xidian University Press, 2002, 286 344. 